\title{
Assessment of Resistance and Bioremediation Ability of Lactobacillus Strains to Lead and Cadmium
}

\author{
Anna V. Kirillova, ${ }^{1}$ Anna A. Danilushkina, ${ }^{2}$ Denis S. Irisov, ${ }^{3}$ Nataliya L. Bruslik, \\ Rawil F. Fakhrullin, ${ }^{1,2}$ Yuri A. Zakharov, ${ }^{3}$ Vladimir S. Bukhmin, ${ }^{3}$ and Dina R. Yarullina ${ }^{1}$ \\ ${ }^{1}$ Department of Microbiology, Kazan Federal University, Kremlevskaya St. 18, Kazan 420008, Russia \\ ${ }^{2}$ Bionanotechnology Lab, Institute of Fundamental Medicine and Biology, Kazan Federal University, Kreml uramı 18, Kazan, \\ Tatarstan 420008, Russia \\ ${ }^{3}$ Institute of Physics, Kazan Federal University, Kremlevskaya St. 16, Kazan 420008, Russia \\ Correspondence should be addressed to Dina R. Yarullina; kasfes@gmail.com
}

Received 5 October 2016; Accepted 15 December 2016; Published 4 January 2017

Academic Editor: Joseph Falkinham

Copyright (C) 2017 Anna V. Kirillova et al. This is an open access article distributed under the Creative Commons Attribution License, which permits unrestricted use, distribution, and reproduction in any medium, provided the original work is properly cited.

Cadmium $(\mathrm{Cd})$ and lead $(\mathrm{Pb})$ are heavy metals, important environmental pollutants, and potent toxicants to organism. Lactic acid bacteria $(\mathrm{LAB})$ have been reported to remove $\mathrm{Cd}$ and $\mathrm{Pb}$ from solutions and therefore represent a useful tool for decontamination of food and beverages from heavy metals. Heavy metal ion binding by LAB was reported as metabolism-independent surface process. In this work ten Lactobacillus strains were investigated with respect to hydrophobicity, Lewis acid-base, and electrostatic properties of their outer cell surface in order to characterize their $\mathrm{Cd}$ and $\mathrm{Pb}$ removal capacity. Seven L. plantarum and L. fermentum strains were shown to remove $\mathrm{Cd}$ from culture medium. The metabolism-dependent accumulation mechanism of Cd removal was proposed based on extended character of $\mathrm{Cd}$ binding and lack of correlation between any of the surface characteristics and Cd removal. The results of this study should be considered when selecting probiotic strains for people at risk of Cd exposure.

\section{Introduction}

Lead $(\mathrm{Pb})$ and cadmium $(\mathrm{Cd})$ are the two most abundant toxic heavy metals in the environment, reported in the Priority List of Hazardous Substances on the 2nd and 7th places, respectively [1]. They are biologically nonessential and nondegradable and tend to accumulate in exposed organisms. $\mathrm{Pb}$ exposure induces neurologic and hematological dysfunctions, cardiovascular, hepatic, and renal damage, and reproductive disorders in the human body. It is particularly harmful to the young children [2]. Cd toxicity is associated primarily with renal, skeletal, and pulmonary dysfunctions [3]; hepatic, reproductive, and cardiovascular disorders are also described [4]. Besides, International Agency for Research on Cancer (IARC) classifies Cd as a group I human carcinogen.

Despite the constitutive efforts to protect the health of children and adults from hazardous heavy metals, occupational and environmental exposures to $\mathrm{Pb}$ and $\mathrm{Cd}$ remain a serious problem in many countries. Lactic acid bacteria
(LAB) and more particularly lactobacilli were reported to bind heavy metals and thus represent a promising approach for decontamination of heavy metals in food and water and perhaps gastrointestinal tract as well, extending areas of LAB applications in food industry and probiotics. In contrast to conventional physicochemical techniques microbial metal ion binding exhibits fine specificity and is environmentally friendly, of low-cost, and efficient at low metal ion concentrations [5]. To date, the ability to bind $\mathrm{Cd}$ and $\mathrm{Pb}$ was reported for several probiotic and food-grade Lactobacillus strains: $L$. rhamnosus GG [5-7], LC705 [6-8], L. johnsonii Lj1 [6], L. casei Shirota [5, 6], and L. fermentum ME3 [5, 9]. In addition, $L$. amylovorus, $L$. reuteri, and $L$. dextrinicus strains, isolated from $\mathrm{Cd}$ - and $\mathrm{Pb}$-contaminated mud and sludge samples, were recognized as $\mathrm{Cd}$ - and $\mathrm{Pb}$-removing probiotic strains [10].

Although social benefit from LAB in bioremediation of contaminated food and humans themselves is well recognized, detoxication mechanisms of lactobacilli are still controversial. Heavy metal binding was reported to be strain, 
temperature, and $\mathrm{pH}$ dependent and happened efficiently at low concentration ranges commonly observed in foods $[6,8]$. Due to rapid uptake of $\mathrm{Cd}$ and $\mathrm{Pb}$ from aqueous solution, the mechanism of passive binding of metal ions to the surface of bacteria was suggested rather than accumulation inside the cell [5]. According to [9], several reversible mechanisms such as ion exchange and precipitation are involved in $\mathrm{Cd}$ and $\mathrm{Pb}$ binding by $\mathrm{LAB}$. Reduction of $\mathrm{Cd}$ and $\mathrm{Pb}$ removal under low $\mathrm{pH}$ [5] and in the presence of other cations [9] supports the idea that metal uptake is determined by physical adsorption. Using electron microscopy and Fourier transform infrared (FTIR) spectroscopy in two Lactobacillus kefir strains, CIDCA 8348 and JCM 5818, it was shown that S-layer proteins interact with $\mathrm{Cd}$ and $\mathrm{Pb}$ and adjust their structure to the presence of the metal ions [11]. Yet, the absence of correlation between cell charge and removal of $\mathrm{Cd}$ and $\mathrm{Pb}$ questions the involvement of electrostatic interactions between heavy metals and LAB [7]. Besides, no data were reported so far about the possibility of accumulation of heavy metals inside Lactobacillus cells.

The aim of this work was to determine the cell surface characteristics and the potential ability to remove $\mathrm{Cd}$ and $\mathrm{Pb}$ from aqueous solutions and culture medium with ten Lactobacillus strains, including four L. plantarum strains, three L. fermentum strains, L. brevis, L. buchneri, and $L$. rhamnosus. Some of these strains were specifically isolated from probiotics, dairy products, and silage. Investigations of hydrophobic/hydrophilic character and Lewis acid-base interactions were performed by using the microbial adhesion to solvents (MATS) method, and electrostatic properties were studied by microelectrophoresis.

\section{Materials and Methods}

2.1. Heavy Metals. $\mathrm{Cd}(2 \mathrm{mg} / \mathrm{mL})$ and $\mathrm{Pb}(2 \mathrm{mg} / \mathrm{mL})$ stock solutions in Milli-Q water were prepared from $\mathrm{Cd}\left(\mathrm{NO}_{3}\right)_{2}$ and $\mathrm{Pb}\left(\mathrm{NO}_{3}\right)_{2}$ (Sigma-Aldrich), respectively. Metal solutions were added to the bacterial culture medium after autoclaving and cooling at c. $40^{\circ} \mathrm{C}$.

2.2. Bacterial Strains. The following Lactobacillus strains were used in this study: Lactobacillus plantarum 8PA3 ("Lactobacterin dry", Biomed, Russia), Lactobacillus plantarum B-578 (All-Russian Collection of Microorganisms, VKM), Lactobacillus plantarum S1 (Silage, Chistopolsky region, Tatarstan Rep., Russia), Lactobacillus plantarum Ga ("Gastropharm," Biovet, Bulgaria), Lactobacillus fermentum $\mathrm{Na}$ ("Narine," Narex, Armenia), Lactobacillus fermentum 3-2 (sour-milk drink "Ayran," FoodMilk), Lactobacillus fermentum 3-3 (sour-milk drink "Dar Gor," FoodMilk), Lactobacillus brevis DSM-20054, Lactobacillus buchneri DSM-20057 (German Collection of Microorganisms and Cell Cultures, DSMZ), and Lactobacillus rhamnosus I2L (Russian National Collection of Industrial Microorganisms, VKPM). Isolation and identification of bacteria are described elsewhere [12].

2.3. Growth Media and Culture Conditions. Lactobacilli were cultured in de Man, Rogosa, Sharpe (MRS) broth (BD Difco) under microaerophilic conditions at $37^{\circ} \mathrm{C}$.
Toxicity of heavy metals was studied using a Tecan Infinite F200 PRO (Switzerland) microplate reader. Overnight cultures of the lactobacilli were diluted 1:50 with fresh MRS broth containing $0-50 \mathrm{mg} / \mathrm{L} \mathrm{Pb}$ or $\mathrm{Cd}$ and loaded into sterile polystyrene 96-well microplates (flat bottom, CellStar Greiner Bio-One). Microplates were incubated at $37^{\circ} \mathrm{C}$ and measurements of the optical density at $600 \mathrm{~nm}\left(\mathrm{OD}_{600}\right)$ were automatically recorded each $30 \mathrm{~min}$ with $20 \mathrm{~s}$ shaking cycles before measurements were started. Growth analysis of the lactobacilli cultures in the presence of $\mathrm{Pb}$ or $\mathrm{Cd}$ was performed along with controls without heavy metals to obtain reference growth curves, as well as with sterile media controls as background readings.

The bacteria for characterization of surface properties were cultured in MRS broth for 18-20 h, harvested by centrifugation at $5000 \mathrm{rpm}$ for $10 \mathrm{~min}$, and washed three times with appropriate $\mathrm{KNO}_{3}$ solution.

The supernatant of the bacteria grown for $24 \mathrm{~h}$ in MRS broth with $5 \mathrm{mg} / \mathrm{L} \mathrm{Pb}$ or Cd was used for measurements of Cd and $\mathrm{Pb}$ concentrations with atomic absorption spectrometry.

\subsection{Surface Characterization of Bacteria}

2.4.1. MATS Method. Microbial adhesion to solvents (MATS) was measured according to the method of Rosenberg et al. [13] with some modifications of Bellon-Fontaine et al. [14]. Bacteria were harvested in the stationary phase by centrifugation at $5000 \mathrm{rpm}$ for $10 \mathrm{~min}$, washed three times, and resuspended to an optical density of 0.4 at $400 \mathrm{~nm}\left(A_{0}\right)$ in $0.1 \mathrm{M} \mathrm{KNO}_{3}$ (pH 6.2). $0.2 \mathrm{~mL}$ of solvent was added to $1.2 \mathrm{~mL}$ of cell suspension. After a $10 \mathrm{~min}$ preincubation at room temperature, the two-phase system was mixed on a vortex for $2 \mathrm{~min}$ and incubated for $15 \mathrm{~min}$ for phase separations. The aqueous phase was gently taken out to measure its optical density at $400 \mathrm{~nm}\left(A_{1}\right)$. The percentage of microbial adhesion to solvent was calculated as $\left(1-A_{1} / A_{0}\right) \times 100$.

Three different solvents were tested in this study: $n$ hexadecane (Sigma-Aldrich), which is an apolar solvent; chloroform (Sigma-Aldrich), a monopolar and acidic solvent; and ethyl acetate (Sigma-Aldrich), a monopolar and basic solvent. Bacterial adhesion to $\mathrm{n}$-hexadecane reflects cell surface hydrophobicity or hydrophilicity. The values of MATS obtained with the two other solvents, chloroform and ethyl acetate, were regarded as a measure of electron donor (basic) and electron acceptor (acidic) characteristics of bacteria, respectively [14].

2.4.2. Zeta Potential. Zeta potential $(\zeta)$ was measured to determine the cell surface net charge of the bacteria. A Zetasizer Nano ZS (Malvern Instruments, UK) was used to measure the electrophoretic mobility, with conversion to zeta potential using Smoluchowski's approximation. Measurements were performed with cells suspended in $1 \mathrm{mM}$ $\mathrm{KNO}_{3}(\mathrm{pH}=6.0)$. The samples were placed into standard $\mathrm{U}$ shaped zeta/size cells and measured in triplicate at $25^{\circ} \mathrm{C}$

The influence of $\mathrm{Cd}$ and $\mathrm{Pb}$ on the bacterial surface charge was also investigated. Prior to the measurements, cells were incubated for $1 \mathrm{~h}$ at $180 \mathrm{rpm}$ in $1 \mathrm{mM} \mathrm{KNO}_{3}(\mathrm{pH}=6.0)$ spiked with $5 \mathrm{mg} / \mathrm{L} \mathrm{Pb}$ or $\mathrm{Cd}$. After that, bacteria were separated 
TABLE 1: Physicochemical properties of bacterial cell surface.

\begin{tabular}{|c|c|c|c|c|}
\hline \multirow{2}{*}{ Species and strains } & \multicolumn{3}{|c|}{$\%$ of adhesion $( \pm S D)^{a}$ to } & \multirow{2}{*}{$\zeta$-potential } \\
\hline & Hexadecane & Ethyl acetate & Chloroform & \\
\hline \multicolumn{5}{|l|}{ L. plantarum } \\
\hline 8PA3 & $9.3 \pm 2.2$ & $34.5 \pm 3.0$ & $17.9 \pm 1.6$ & $-24.8 \pm 2.5$ \\
\hline B-578 & $52.0 \pm 6.4$ & $19.1 \pm 2.0$ & $88.8 \pm 3.6$ & $-27.6 \pm 1.9$ \\
\hline S1 & $6.6 \pm 1.6$ & $15.1 \pm 2.3$ & $29.3 \pm 3.4$ & $-34.9 \pm 2.3$ \\
\hline $\mathrm{Ga}$ & $17.6 \pm 3.8$ & $14.6 \pm 2.8$ & $29.9 \pm 2.6$ & $-12.1 \pm 1.2$ \\
\hline \multicolumn{5}{|l|}{ L. fermentum } \\
\hline $\mathrm{Na}$ & $20.8 \pm 3.1$ & $18.4 \pm 2.7$ & $9.8 \pm 1.2$ & $-11.3 \pm 0.7$ \\
\hline $3-2$ & $27.9 \pm 3.3$ & $23.8 \pm 2.2$ & $93.8 \pm 2.2$ & $-19.3 \pm 1.8$ \\
\hline $3-3$ & $8.7 \pm 1.8$ & $10.7 \pm 1.6$ & $20.1 \pm 2.1$ & $-7.4 \pm 0.9$ \\
\hline L. brevis 20054 & $63.1 \pm 5.6$ & $26.5 \pm 2.0$ & $94.6 \pm 0.1$ & $-14.8 \pm 1.8$ \\
\hline L. buchneri 20057 & $66.9 \pm 6.3$ & $35.6 \pm 3.1$ & $97.1 \pm 0.1$ & $-20.7 \pm 1.7$ \\
\hline L. rhamnosus $\mathrm{I} 2 \mathrm{~L}$ & $28.7 \pm 3.3$ & $21.3 \pm 2.7$ & $34.8 \pm 4.0$ & $-21.5 \pm 2.2$ \\
\hline
\end{tabular}

${ }^{\mathrm{a}}$ Means \pm standard deviations of two measures of three separate experiments.

by centrifugation at $5000 \mathrm{rpm}$ for $5 \mathrm{~min}$ and resuspended in $1 \mathrm{mM} \mathrm{KNO}_{3}(\mathrm{pH}=6.0)$.

2.4.3. Measurement of Cadmium and Lead. $\mathrm{Pb}$ and Cd concentrations in the supernatants were measured using atomic absorption spectrometer MGA-915 MD (Lumex, Russia) with graphite tube atomizer and autosampler. Standard pyrocoated graphite furnaces (length $28 \mathrm{~mm}$, internal diameter $6 \mathrm{~mm}$ ) with longitudinal heating (PerkinElmer, USA) and high pure argon for inert atmosphere were applied. The spectrometer was equipped with special accessory for twostage probe atomization Atzond-1 (Atzond, Russia). Samples of MRS broth spiked with $5 \mathrm{mg} / \mathrm{L} \mathrm{Pb}$ or $\mathrm{Cd}$ were used as quality control samples. Metal removal rate was expressed in percentage. Changes of metal concentration in the samples over $3 \%(\mathrm{~Pb})$ and $7 \%(\mathrm{Cd})$ can be clearly distinguished at $P=0.7$.

2.5. Statistical Analysis. All experiments were independently conducted two or three times, and each assay was performed in triplicate. The results were expressed as the means \pm standard deviation. Student's $t$-test (for paired or unpaired samples) was used to compare the results; the differences were considered significant when $P<0.05$. For correlations, the Pearson correlation coefficient $(r)$ was used.

\section{Results}

3.1. Toxicity of $\mathrm{Cd}$ and $\mathrm{Pb}$ towards Lactobacillus. The lowest tested concentration of $\mathrm{Cd}(5 \mathrm{mg} / \mathrm{L})$ showed no influence on the growth of lactobacilli except L. fermentum 3-2, in which presence of $5 \mathrm{mg} / \mathrm{L} \mathrm{Cd}$ led to decrease of maximum optical density values (see Supplemental Figure S2(b) available online at https://doi.org/10.1155/2017/9869145). Furthermore, in L. plantarum 8PA3 and L. fermentum, 3-2 cultures with $5 \mathrm{mg} / \mathrm{L} \mathrm{Cd}$ slopes of the growth curves during the exponential phase were slightly higher than those in Cd-free controls (Supplemental Figures S1(a) and S2(a)). Application of $10 \mathrm{mg} / \mathrm{L} \mathrm{Cd}$ resulted in reduced $\mathrm{OD}_{600}$ values in the stationary phase of L. plantarum 8PA3, L. plantarum B-578, and L. fermentum 3-2 cultures and totally inhibited growth of L. brevis 20054, L. buchneri 20057, and L. rhamnosus I2L. $\mathrm{Cd}$ in the highest tested concentration $(50 \mathrm{mg} / \mathrm{L})$ was toxic for all tested lactobacilli. Specifically, cultures of $L$. plantarum and L. fermentum exhibited significant reduction in growth rate and cultures of L. brevis 20054, L. buchneri 20057, and L. rhamnosus I2L did not show bacterial growth within $18 \mathrm{~h}$ (Figure 1, Supplemental Figures S1-S3).

In all tested cultures addition of $\mathrm{Pb}$ at concentrations 5 and $10 \mathrm{mg} / \mathrm{L}$ resulted in a shallower growth curve slope and extended lag phase compared with $\mathrm{Pb}$-free controls. Furthermore, despite the delayed onset of growth and lower growth rate, the addition of $\mathrm{Pb}$ at these concentrations did not lead to lower maximum optical density values in lactobacilli cultures except L. plantarum S1, in which $\mathrm{Pb}$ led to decrease of $\mathrm{OD}_{600}$ on $14.5 \%$ and $30.4 \%$ at 5 and $10 \mathrm{mg} / \mathrm{L}$ $\mathrm{Pb}$, correspondingly (Figure 1(a)). Concentration $50 \mathrm{mg} / \mathrm{L}$ $\mathrm{Pb}$ revealed complete growth inhibition in all lactobacilli cultures (Figure 1, Supplemental Figures S1-S3).

3.2. Physicochemical Properties of Bacterial Cell Surface. The adhesive characteristics of Lactobacillus strains to nhexadecane, chloroform, and ethyl acetate are shown in Table 1 . The results indicated that most strains were fully hydrophilic, since very low percentages of bacteria (6.6$28.7 \%)$ adhered to n-hexadecane, an apolar solvent. The most hydrophobic strains were L. plantarum B-578 (52.0 $\pm 6.4 \%)$, L. brevis $20054(63.1 \pm 5.6 \%)$, and L. buchneri 20057 (66.9 \pm $6.3 \%)$.

Bacterial adhesion to chloroform and ethyl acetate was tested to assess the Lewis acid-base characteristics of the bacterial cell surfaces. The affinities with chloroform, which is an acidic solvent and electron acceptor, varied significantly between tested strains. The least affinity with chloroform was observed in $L$. fermentum $\mathrm{Na}(9.8 \pm 1.2 \%)$, while the greatest affinities were observed in L. plantarum B-578 (88.8 $\pm 3.6 \%)$, L. fermentum 3-2 (93.8 $\pm 2.2 \%)$, L. brevis 20054 (94.6 $\pm 0.1 \%)$, and L. buchneri $20057(97.1 \pm 0.1 \%)$. Adhesion to ethyl acetate, which is a basic solvent and electron donor, was low with all bacteria studied, ranging from $14.6 \pm 2.8 \%$ to $35.6 \pm 3.1 \%$. 


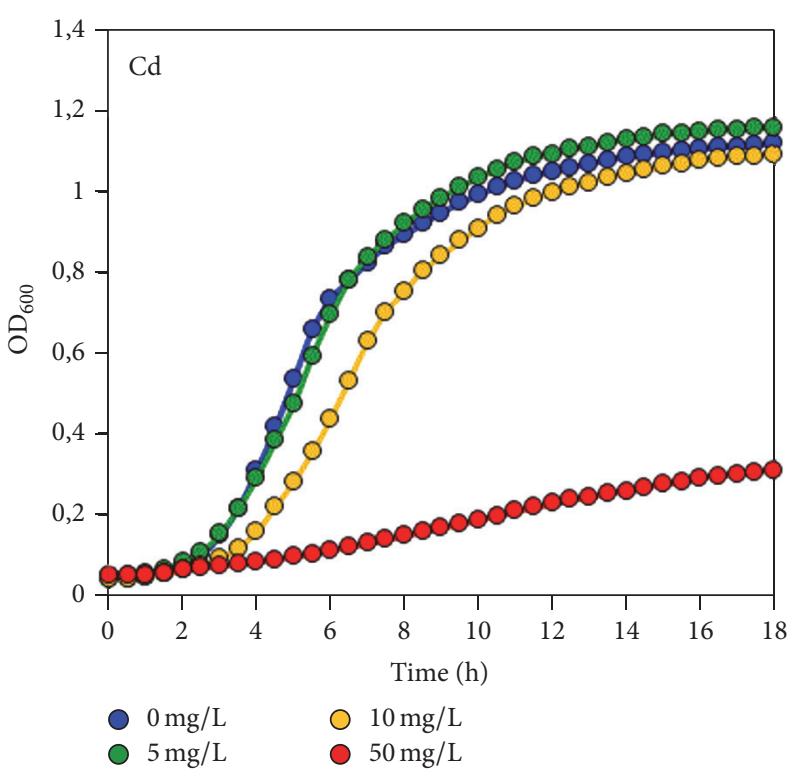

(a)

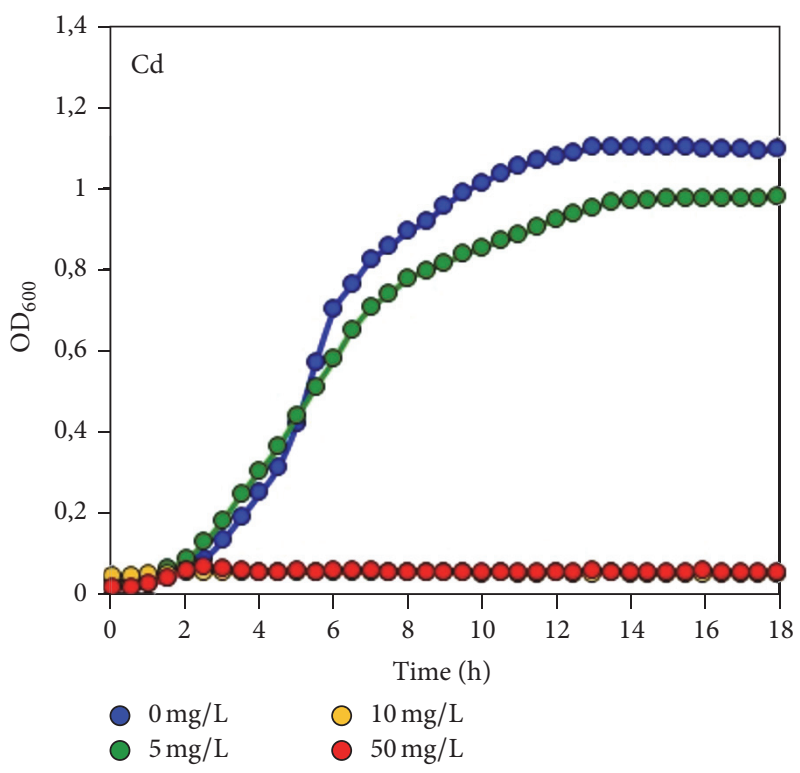

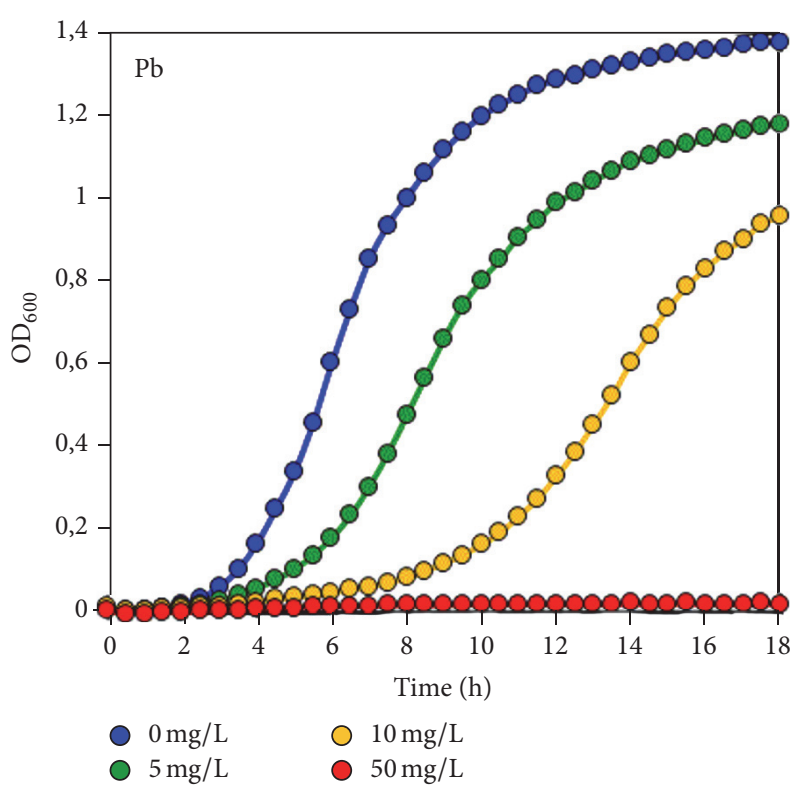

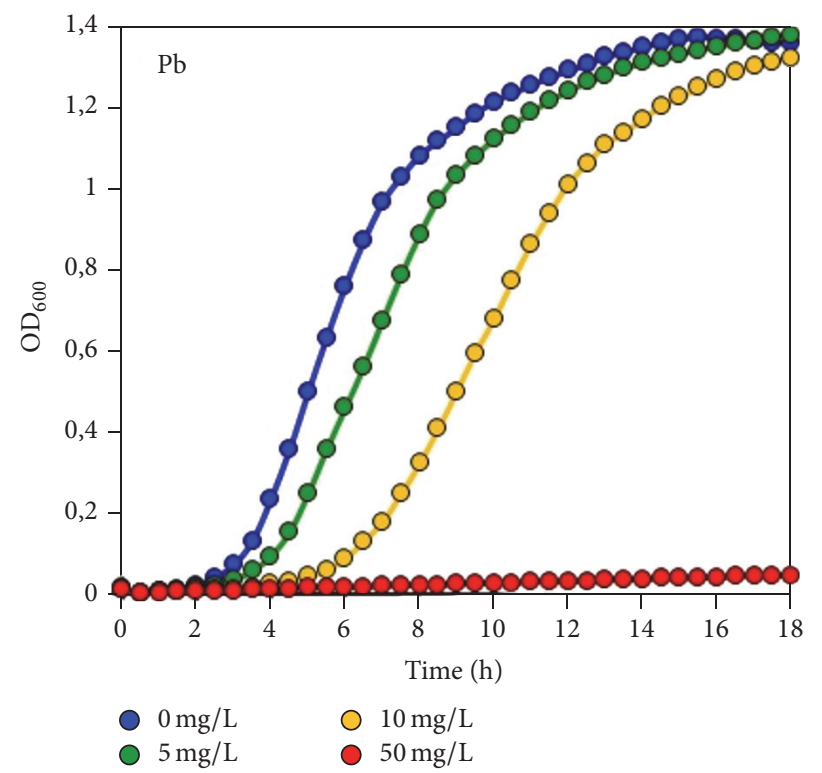

(b)

FIGURE 1: Growth of Lactobacillus plantarum S1 (a) and L. buchneri 20057 (b) in the presence of Cd or Pb (see growth curves of all Lactobacillus strains in Supplemental Figures S1-S3).

The cell surface net charge of the bacteria was examined by microelectrophoresis, which measures zeta potentials of microorganisms in the stationary phase. $\mathrm{KNO}_{3}$ solution was used as reference medium to avoid nonspecific absorption of ions on cell surfaces [15]. In general, the net surface charge of the studied strains was negative, ranging from $-34.9 \pm$ $6.8 \mathrm{mV}$ (L. plantarum S1) to $-7.4 \pm 0.9 \mathrm{mV}$ (L. fermentum 3-3) (Table 1). Furthermore, zeta potentials differed significantly both between species and strains.

3.3. Binding of $C d$ and $P b$ by Lactobacillus Cells. First, the potential of Lactobacillus cells to bind heavy metals was studied as the difference in cell surface net charge after incubation with $\mathrm{Cd}$ or $\mathrm{Pb}$. A contact time of $1 \mathrm{~h}$ was chosen according to Halttunen et al. [5]. In all Lactobacillus strains after $1 \mathrm{~h}$ incubation in aqueous solutions containing $10 \mathrm{mg} / \mathrm{L}$ of $\mathrm{Cd}$ or $\mathrm{Pb}$, differences towards more positive zeta potentials were not observed (not presented). Conversely, cell surface electronegativity decreased after incubation with $\mathrm{Cd}$ and $\mathrm{Pb}$, but reductions were not statistically significant.

The removal of $\mathrm{Cd}$ and $\mathrm{Pb}$ from MRS broth is presented in Table 2. Lactobacillus cells did not remove $\mathrm{Pb}$ from MRS broth, nor did L. brevis 20054, L. buchneri 20057, and L. rhamnosus I2L with $\mathrm{Cd}$. L. plantarum and L. fermentum 
TABLE 2: Removal of Cd from MRS broth by Lactobacillus strains.

\begin{tabular}{lc}
\hline Species and strains & \% Cd removed \\
\hline L. plantarum & 8 \\
8 PA3 & 16 \\
B-578 & 8 \\
S1 & 8 \\
Ga & \\
L. fermentum & \\
Na & 4 \\
3-2 & 8 \\
3-3 & 12 \\
L. brevis 20054 & 0 \\
L. buchneri 20057 & 0 \\
L. rhamnosus I2L & 0 \\
\hline
\end{tabular}

The bacteria were incubated $24 \mathrm{~h}$ in MRS broth supplemented with $5 \mathrm{mg} / \mathrm{L}$ Cd.

strains demonstrated removal of $\mathrm{Cd}$, ranging from 8 to $16 \%$. The most efficient removal of $\mathrm{Cd}$ was observed with $L$. plantarum B-578 (16\%). However, no correlation between any of the surface characteristics and removal of $\mathrm{Cd}$ was observed.

\section{Discussion}

The results demonstrate that Lactobacillus strains were highly tolerant to Cd and Pb. L. brevis 20054, L. buchneri 20057, and L. rhamnosus I2L were most sensitive to heavy metals because they demonstrated considerable growth reduction at 10 and $50 \mathrm{mg} / \mathrm{L}$ of Cd whereas L. fermentum and L. plantarum strains continued to grow at these concentrations. Bhakta et al. [10] showed that $\mathrm{Pb}$ and $\mathrm{Cd}$ resistant Lactobacillus strains more likely demonstrated increased $\mathrm{Pb}$ and $\mathrm{Cd}$ removal efficiency. $L$. fermentum and L. plantarum strains are therefore considered to be potential $\mathrm{Pb}$ and $\mathrm{Cd}$ removing bacteria.

There are two basic mechanisms of metal ion binding by microorganisms: bioaccumulation-metabolism associated process in which metal ions penetrate plasma membrane and accumulate inside the cell-and biosorption-the metabolism-independent binding of metal ions to the cell surface [16]. Mechanisms such as adsorption, ion exchange, complexation, chelation, and microprecipitation have been proposed to be involved in metal biosorption [17]. Since metal ion binding is a surface process we assessed physicochemical properties of Lactobacillus cells and their impact on binding of $\mathrm{Pb}$ and $\mathrm{Cd}$.

First, cell surface hydrophobicity was examined by measuring microbial adhesion to n-hexadecane in a two-phase system. The results indicated that most microorganisms studied were relatively hydrophilic (Table 1). The hydrophilic nature of lactobacilli has often been encountered in previous studies $[15,18,19]$. Three strains, L. plantarum B$578(52.0 \pm 6.4 \%)$, L. brevis $20054(63.1 \pm 5.6 \%)$, and L. buchneri $20057(66.9 \pm 6.3 \%)$, were hydrophobic. The hydrophobic/hydrophilic properties resulted from proteins and polysaccharides on the bacterial cell surface. The presence of proteinaceous compounds at the cell surface results in a higher hydrophobicity [20-22], whereas a hydrophilic surface is associated with the presence of polysaccharides [22-24]. (Lipo)teichoic acids, which are hydrophobic, might have an effect on hydrophobicity as well, but it is unclear $[22,25]$. It is well known that lactobacilli show great diversity in cell surface structure and composition and are able to modify their surface properties in response to environmental changes [26]. In all probabilities, species and strain specific variations in the cell surface hydrophobicity result from different expression of certain surface components (adhesins, polysaccharides, and proteins).

Further chloroform and ethyl acetate were used to assess the electron donor (basic) and electron acceptor (acidic) characteristics of bacterial surface, respectively (Table 1), which are attributed to Lewis acid-base interactions $[14,15]$. The bacterial affinities to ethyl acetate were low in all strains tested indicating the nonacidic and poor electron acceptor properties of lactobacilli. The high affinities to chloroform in L. plantarum B-578 $(88.8 \pm 3.6 \%)$, L. fermentum 3-2 (93.8 \pm 2.2\%), L. brevis 20054 (94.6 $\pm 0.1 \%)$, and L. buchneri 20057 $(97.1 \pm 0.1 \%)$ indicate the basic (electron donor) character of the bacterial cell, which is probably related to the presence of a carboxylic $\left(-\mathrm{COO}^{-}\right)$and hydrogen sulfite $\left(-\mathrm{HSO}_{3}{ }^{-}\right)$groups on the microbial surface $[14,15]$.

We subsequently studied electrostatic cell surface properties of lactobacilli by measuring the electrophoretic mobility in microelectrophoresis, which is a common method to determine cell surface charge. All Lactobacillus strains displayed an overall electronegative charge, which differed between species and strains from $-7.4 \pm 0.9$ to $-34.9 \pm$ $6.8 \mathrm{mV}$, similar to zeta potential profiles that were previously reported for other lactobacilli $[15,18,22,24,25]$. Such profiles indicate that the surface of the cells was to large extent dominated by anionic compounds, such as phosphate groups, involved in (lipo)teichoic acids, and carboxylate groups of acidic polysaccharides and proteins [22, 23]. Strikingly, no relationships seemed to exist between the electrostatic properties and the electron donor or electron acceptor profile of the microorganisms $(r=0.17$ and $r=0.24$, resp.). This result is consistent with earlier data of Pelletier et al. [15].

Several reports indicate involvement of electrostatic interactions in bacterial binding of heavy metals. This notice is supported by $\mathrm{pH}$ dependent manner of $\mathrm{Cd}$ and $\mathrm{Pb}$ binding by Bacillus subtilis [27], Pseudomonas putida [28], Citrobacter sp. [29], L. rhamnosus GG, L. fermentum ME3, B. lactis Bb12, and $B$. longum 46 [5]. Reduced metal binding at lower $\mathrm{pH}$ may result from competition for negatively charged binding sites between heavy metal cations and protons $\left(\mathrm{H}^{+}\right)[30]$. Similarly, the presence of other cations reduced $\mathrm{Cd}$ and $\mathrm{Pb}$ binding with L. fermentum ME3 and B. longum 46, probably, due to competition between these metals for the binding sites [9]. Involvement of anionic surface groups in metal binding with $L$. fermentum ME3, B. longum 46, and isolated B. subtilis cell walls was also verified by reduction of cation uptake after inactivation of phosphoryl and carboxyl groups [9, 31, 32].

Our results of physicochemical properties indicated electronegative nonacidic character of all lactobacilli tested. Four strains, namely, L. plantarum B-578, L. fermentum 3-2, L. brevis 20054, and L. buchneri 20057, possessed strong electron 
donor properties and were therefore considered to have the larger potential for metal binding among tested lactobacilli. According to zeta potential profile, L. plantarum S1, which showed the most negative surface charge, has the strongest potential for metal binding. Yet, its high electronegativity is not confirmed by weak electron donor properties. The surface of Lactobacillus cells, like other Gram-positive bacteria, is composed of a thick peptidoglycan layer, (lipo)teichoic acids, polysaccharides, and proteins, including S-layer (glycol)proteins [26]. These structures contain different kinds of charged groups like carboxyl, hydroxyl, and phosphate groups. Lactobacilli have therefore a great number of different possible ligands capable of binding cationic ions like $\mathrm{Pb}$ and Cd.

To test $\mathrm{Cd}$ and $\mathrm{Pb}$ binding by lactobacilli we employed two different approaches. First, the differences of cell charge were measured after $1 \mathrm{~h}$ contact with heavy metals, but no shift towards more positive zeta potentials was detected. These results indicate that lactobacilli did not bind $\mathrm{Cd}$ and $\mathrm{Pb}$ ions at these conditions. Next, we studied the decrease of $\mathrm{Cd}$ and $\mathrm{Pb}$ concentrations in MRS broth after $24 \mathrm{~h}$ growth and showed that L. plantarum and L. fermentum strains removed Cd from culture medium (Table 2). Yet, this removal was much lower compared to that previously reported for $L$. fermentum ME3 [5, 9].

No relationship between heavy metal removal and tolerance was indicated. It should be noted that three strains, $L$. brevis 20054, L. buchneri 20057, and L. rhamnosus I2L, which demonstrated the strongest sensitiveness to $\mathrm{Cd}$, were not able to bind it. Meanwhile, L. fermentum Na, tolerant to all Cd concentrations studied, did not remove its ions from culture medium. Earlier the absence of clear relationship between the resistant patterns and metal removal efficiencies was reported for other $\mathrm{LAB}$, thus indicating the existence of variations in resistant mechanism among the LAB [10].

In agreement with other studies of Halttunen et al. [7], no correlation between any of the surface characteristics (hydrophobicity, Lewis acid-base properties, and surface charge) and removal of $\mathrm{Cd}$ and $\mathrm{Pb}$ was observed. These paradoxical data may result from metabolism-dependent accumulation of $\mathrm{Cd}$ inside the bacteria, which does not depend much on physical properties of cell surface. Extended character of $\mathrm{Cd}$ removal by tested lactobacilli, which occurred during $24 \mathrm{~h}$ incubation, but not within $1 \mathrm{~h}$, favors accumulation mechanism of metal ion binding, rather than biosorption. Studies on $\mathrm{Pb}$ and $\mathrm{Cd}$ are often conducted together, as the elements seem to react with bacterial species in similar ways. Yet, we did not observe removal of $\mathrm{Pb}$ with all tested Lactobacillus strains, while L. plantarum and L. fermentum strains removed Cd from culture medium. Perhaps, this difference results from larger ionic radius of $\mathrm{Pb}$ if compared with Cd.

According to Monachese et al. [33], bioaccumulation and biosorption of heavy metals by LAB both are prosperous detoxification strategies as they prevent the exposure of heavy metals to body cells and tissues. Our current work expands knowledge about cell surface of lactobacilli and reveals Cd decontamination potential of four L. plantarum and three L. fermentum strains, six with known probiotic properties and one firstly isolated from silage. Continued investigation should provide deeper understanding of mechanisms underpinning Cd removal and application of the microorganisms in dietary strategies for people at risk of Cd exposure.

\section{Competing Interests}

The authors declare that they have no competing interests.

\section{Acknowledgments}

This work was supported by the Russian Government Program for competitive growth of Kazan Federal University, the Russian Science Foundation Grant no. 15-14-00046, and RFBR Grant no. 14-34-50478 and partially by RFBR Grant no. 14-14-00924 (microbial cell surface characterization).

\section{References}

[1] Agency for Toxic Substances and Disease Registry (ATSDR), CERCLA Priority List of Hazardous Substances, U.S. Department of Health and Human Services, Atlanta, Ga, USA, 2015, http://www.atsdr.cdc.gov/SPL/index.html.

[2] E. Rossi, "Low level environmental lead exposure-a continuing challenge," The Clinical Biochemist Reviews, vol. 29, pp. 63-70, 2008.

[3] A. Bernard, "Cadmium and its adverse effects on human health," Indian Journal of Medical Research, vol. 128, no. 4, pp. 557-564, 2008.

[4] J. Godt, F. Scheidig, C. Grosse-Siestrup et al., "The toxicity of cadmium and resulting hazards for human health," Journal of Occupational Medicine and Toxicology, vol. 1, no. 1, article 22, 2006.

[5] T. Halttunen, S. Salminen, and R. Tahvonen, "Rapid removal of lead and cadmium from water by specific lactic acid bacteria," International Journal of Food Microbiology, vol. 114, no. 1, pp. 3035, 2007.

[6] T. Halttunen, P. Kankaanpää, R. Tahvonen, S. Salminen, and A. C. Ouwehand, "Cadmium removal by lactic acid bacteria," Bioscience and Microflora, vol. 22, pp. 93-97, 2003.

[7] T. Halttunen, M. C. Collado, H. El-Nezami, J. Meriluoto, and S. Salminen, "Combining strains of lactic acid bacteria may reduce their toxin and heavy metal removal efficiency from aqueous solution," Letters in Applied Microbiology, vol. 46, no. 2, pp. 160$165,2008$.

[8] F. Ibrahim, T. Halttunen, R. Tahvonen, and S. Salminen, "Probiotic bacteria as potential detoxification tools: assessing their heavy metal binding isotherms," Canadian Journal of Microbiology, vol. 52, no. 9, pp. 877-885, 2006.

[9] H. Teemu, S. Seppo, M. Jussi, T. Raija, and L. Kalle, "Reversible surface binding of cadmium and lead by lactic acid and bifidobacteria," International Journal of Food Microbiology, vol. 125, no. 2, pp. 170-175, 2008.

[10] J. N. Bhakta, K. Ohnishi, Y. Munekage, K. Iwasaki, and M. Q. Wei, "Characterization of lactic acid bacteria-based probiotics as potential heavy metal sorbents," Journal of Applied Microbiology, vol. 112, no. 6, pp. 1193-1206, 2012.

[11] E. Gerbino, P. Mobili, E. Tymczyszyn, R. Fausto, and A. Gómez-Zavaglia, "FTIR spectroscopy structural analysis of the interaction between Lactobacillus kefir S-layers and metal ions," 
Journal of Molecular Structure, vol. 987, no. 1-3, pp. 186-192, 2011.

[12] N. L. Bruslik, D. R. Akhatova, A. A. Toimentseva, S. R. Abdulkhakov, O. N. Ilyinskaya, and D. R. Yarullina, "Estimation of probiotic lactobacilli drug resistance," Antibiotiki i Khimioterapiya, vol. 60, no. 3-4, pp. 6-13, 2015.

[13] M. Rosenberg, D. Gutnick, and E. Rosenberg, "Adherence of bacteria to hydrocarbons: a simple method for measuring cell-surface hydrophobicity," FEMS Microbiology Letters, vol. 9, no. 1, pp. 29-33, 1980.

[14] M.-N. Bellon-Fontaine, J. Rault, and C. J. Van Oss, "Microbial adhesion to solvents: a novel method to determine the electron-donor/electron-acceptor or Lewis acid-base properties of microbial cells," Colloids and Surfaces B: Biointerfaces, vol. 7, no. 1-2, pp. 47-53, 1996.

[15] C. Pelletier, C. Bouley, C. Cayuela, S. Bouttier, P. Bourlioux, and M.-N. Bellon-Fontaine, "Cell surface characteristics of Lactobacillus casei subsp. casei, Lactobacillus paracasei subsp. paracasei, and Lactobacillus rhamnosus strains," Applied and Environmental Microbiology, vol. 63, no. 5, pp. 1725-1731, 1997.

[16] J. Mrvčić, D. Stanzer, E. Šolić, and V. Stehlik-Tomas, "Interaction of lactic acid bacteria with metal ions: opportunities for improving food safety and quality," World Journal of Microbiology and Biotechnology, vol. 28, no. 9, pp. 2771-2782, 2012.

[17] K. J. Blackwell, I. Singleton, and J. M. Tobin, "Metal cation uptake by yeast: a review," Applied Microbiology and Biotechnology, vol. 43, no. 4, pp. 579-584, 1995.

[18] G. Reid, P. L. Cuperus, A. W. Bruce et al., "Comparison of contact angles and adhesion to hexadecane of urogenital, dairy, and poultry lactobacilli: effect of serial culture passages," Applied and Environmental Microbiology, vol. 58, no. 5, pp. 1549-1553, 1992.

[19] R. K. Duary, Y. S. Rajput, V. K. Batish, and S. Grover, "Assessing the adhesion of putative indigenous probiotic lactobacilli to human colonic epithelial cells," Indian Journal of Medical Research, vol. 134, no. 11, pp. 664-671, 2011.

[20] B. Kos, J. Šušković, S. Vuković, M. Šrmpraga, J. Frece, and S. Matošić, "Adhesion and aggregation ability of probiotic strain Lactobacillus acidophilus M92," Journal of Applied Microbiology, vol. 94, no. 6, pp. 981-987, 2003.

[21] H. C. Van Der Mei, B. Van De Belt-Gritter, P. H. Pouwels, B. Martinez, and H. J. Busscher, "Cell surface hydrophobicity is conveyed by S-layer proteins-a study in recombinant lactobacilli," Colloids and Surfaces B: Biointerfaces, vol. 28, no. 2-3, pp. 127-134, 2003.

[22] G. Deepika, R. J. Green, R. A. Frazier, and D. Charalampopoulos, "Effect of growth time on the surface and adhesion properties of Lactobacillus rhamnosus GG," Journal of Applied Microbiology, vol. 107, no. 4, pp. 1230-1240, 2009.

[23] C. J. P. Boonaert and P. G. Rouxhet, "Surface of lactic acid bacteria: relationships between chemical composition and physicochemical properties," Applied and Environmental Microbiology, vol. 66, no. 6, pp. 2548-2554, 2000.

[24] E. Dertli, M. J. Mayer, and A. Narbad, "Impact of the exopolysaccharide layer on biofilms, adhesion and resistance to stress in Lactobacillus johnsonii FI9785," BMC Microbiology, vol. 15, no. 1, article no. 347, 2015.

[25] P. Schaer-Zammaretti and J. Ubbink, "Imaging of lactic acid bacteria with AFM-elasticity and adhesion maps and their relationship to biological and structural data," Ultramicroscopy, vol. 97, no. 1-4, pp. 199-208, 2003.
[26] R. Sengupta, E. Altermann, R. C. Anderson, W. C. McNabb, P. J. Moughan, and N. C. Roy, "The role of cell surface architecture of lactobacilli in host-microbe interactions in the gastrointestinal tract," Mediators of Inflammation, vol. 2013, Article ID 237921, 16 pages, 2013.

[27] J. B. Fein, C. J. Daughney, N. Yee, and T. A. Davis, "A chemical equilibrium model for metal adsorption onto bacterial surfaces," Geochimica et Cosmochimica Acta, vol. 61, no. 16, pp. 3319-3328, 1997.

[28] R. Pardo, M. Herguedas, E. Barrado, and M. Vega, "Biosorption of cadmium, copper, lead and zinc by inactive biomass of Pseudomonas putida," Analytical and Bioanalytical Chemistry, vol. 376, no. 1, pp. 26-32, 2003.

[29] P. R. Puranik and K. M. Paknikar, "Biosorption of lead, cadmium, and zinc by Citrobacter strain MCM B-181: characterization studies," Biotechnology Progress, vol. 15, pp. 228-237, 1999.

[30] C. Huang, C. P. Huang, and A. L. Morehart, "Proton competition in $\mathrm{Cu}$ (II) adsorption by fungal mycelia," Water Research, vol. 25, no. 11, pp. 1365-1375, 1991.

[31] T. J. Beveridge and R. G. E. Murray, "Sites of metal deposition in the cell wall of Bacillus subtilis," Journal of Bacteriology, vol. 141, no. 2, pp. 876-887, 1980.

[32] R. J. Doyle, T. H. Matthews, and U. N. Streips, "Chemical basis for selectivity of metal ions by the Bacillus subtilis cell wall," Journal of Bacteriology, vol. 143, no. 1, pp. 471-480, 1980.

[33] M. Monachese, J. P. Burton, and G. Reid, "Bioremediation and tolerance of humans to heavy metals through microbial processes: a potential role for probiotics?" Applied and Environmental Microbiology, vol. 78, no. 18, pp. 6397-6404, 2012. 

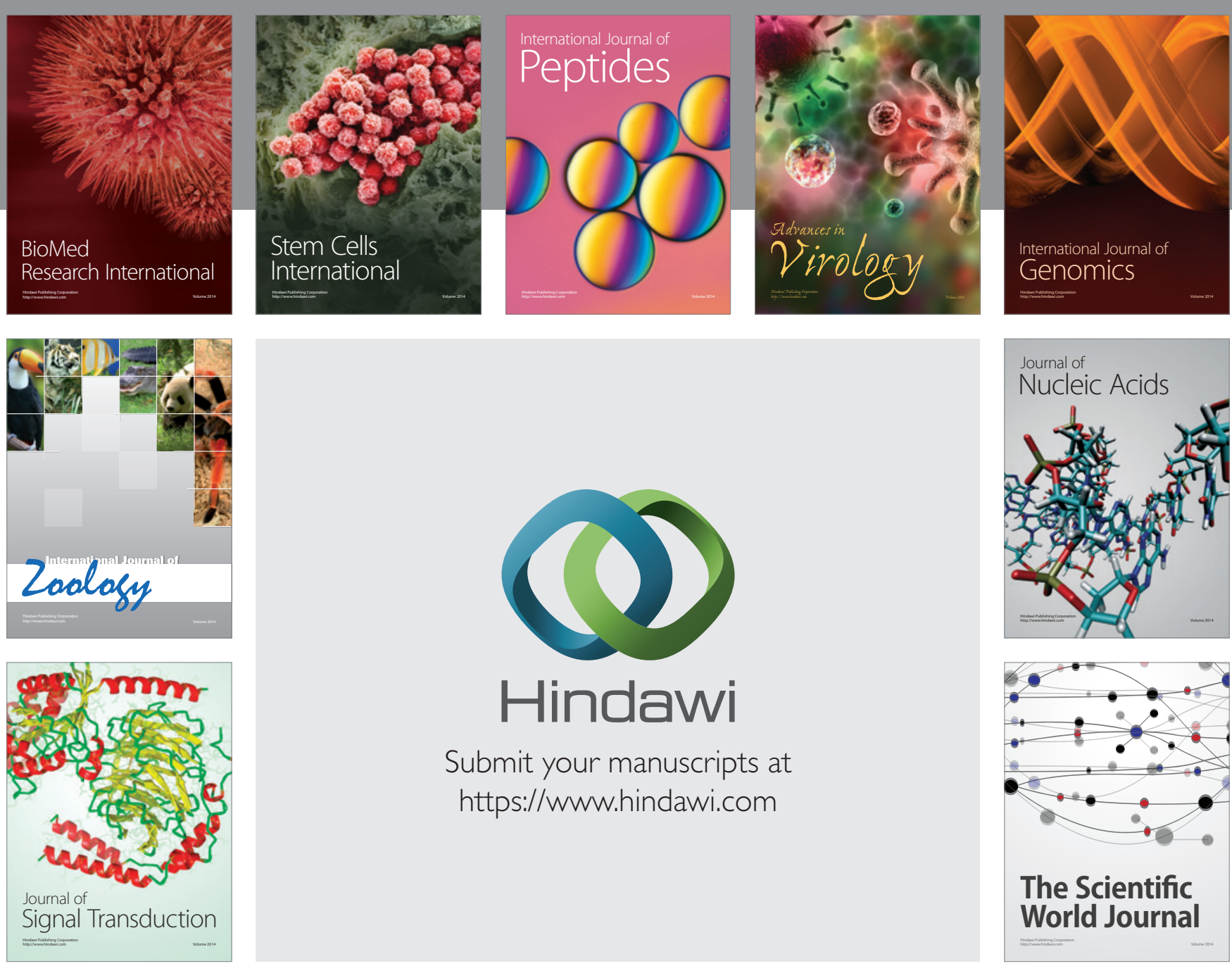

Submit your manuscripts at

https://www.hindawi.com
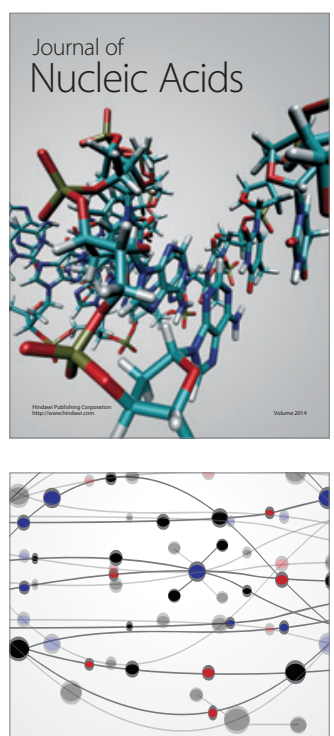

The Scientific World Journal
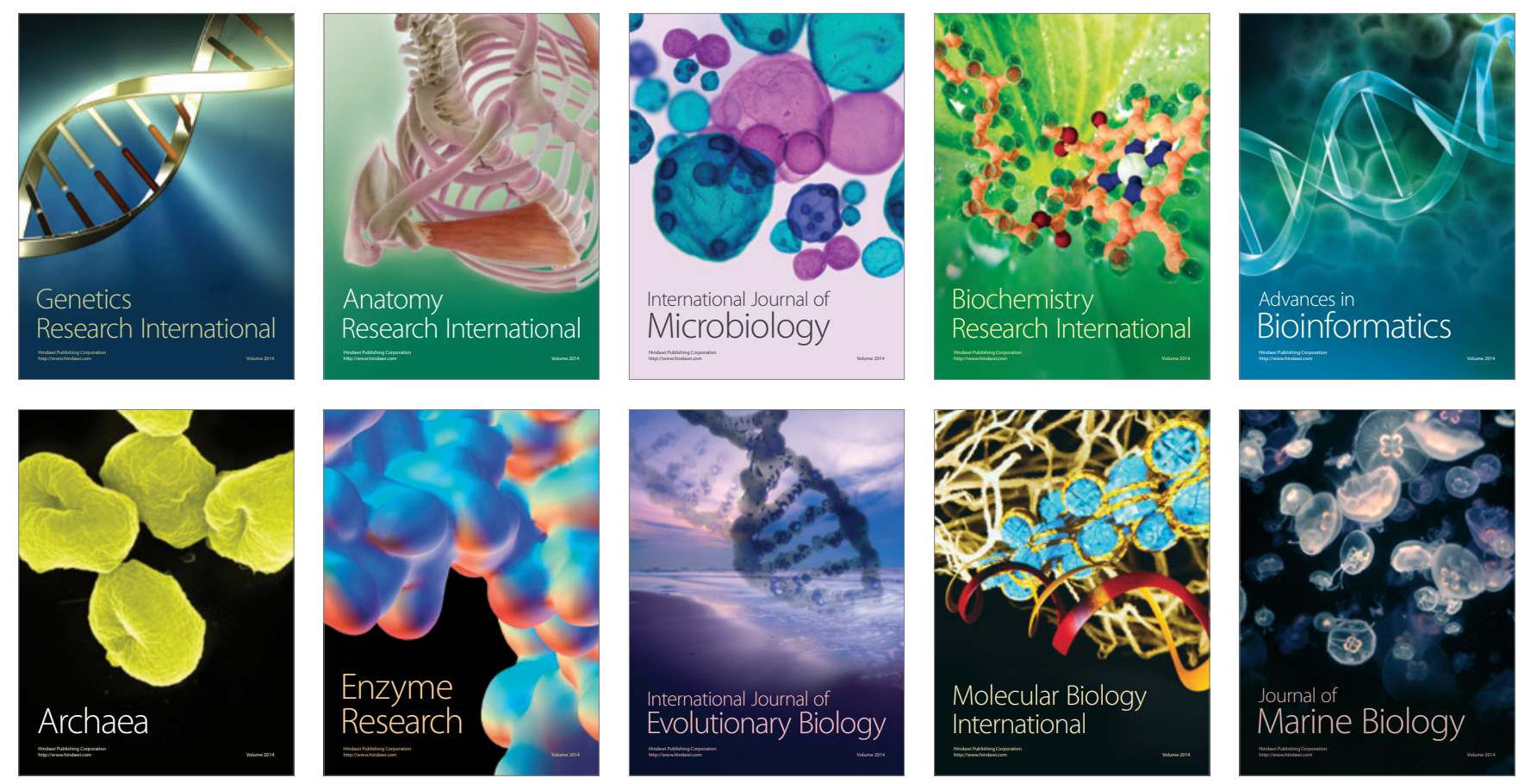